\title{
Immobilization of chemically modified horseradish peroxidase within activated alginate beads
}

\author{
Dragica Spasojević ${ }^{1}$, Miloš Prokopijević ${ }^{1}$, Olivera Prodanović ${ }^{1}$, Marilen Gabriel Pirtea ${ }^{2}$, Ksenija Radotić ${ }^{1}$, \\ Radivoje Prodanović ${ }^{3}$ \\ ${ }^{1}$ Institute for multidisciplinary studies, University of Belgrade, Belgrade, Serbia \\ ${ }^{2}$ Multidisciplinary research platform „Nicholas Georgescu-Roegen", West University of Timisoara, Timisoara, Romania \\ ${ }^{3}$ Faculty of Chemistry, University of Belgrade, Belgrade, Serbia
}

\begin{abstract}
Immobilization of horseradish peroxidase (HRP) within alginate beads was enabled by chemical modification of the enzyme and polysaccharide chains. HRP and alginate were oxidized by periodate and subsequently modified with ethylenediamine. Highest specific activity of $0.43 \mathrm{U} / \mathrm{ml}$ of gel and $81 \%$ of bound enzyme activity was obtained using aminated HRP and alginate oxidized by periodate. Immobilized enzyme retained $75 \%$ of its original activity after 2 days of incubation in $80 \%(\mathrm{v} / \mathrm{v})$ dioxane and had increased activity in basic solutions compared to native enzyme. During repeated use in batch reactor for pyrogallol oxidation immobilized peroxidase retained $75 \%$ of its original activity.
\end{abstract}

Keywords: periodate, ethylene diamine, peroxidase, immobilized.

\section{SCIENTIFIC PAPER}

UDC 66.094.3.097:547.313.2:547.415.1

Hem. Ind. 68 (1) 117-122 (2014)

doi: 10.2298/HEMIND121122036S

Available online at the Journal website: http://www.ache.org.rs/HI/

Horseradish peroxidase (HRP) is one of the most studied peroxidases from plants that can be used for organic synthesis of chemicals like DOPA and bisphenols [1], for removal of polutants such as phenol and aniline from wastewaters [2] and for manufacturing of biosensors [3].

In order to be used in industry, it is necessary to decrease the cost of the enzyme. This can be achieved by repeated use of the same enzyme batch for prolonged period of time. In order to do so, it is necessary to develop efficient method for enzyme immobilization that will facilitate easy removal of the catalyst from reaction mixture without leaking or losing activity [4]. Immobilization within alginate is one of the most common methods for enzyme and cell immobilization since it does not require expensive chemicals or complicated setup [5]. Since alginate macromolecular gel has large pore diameter, low molecular weight enzymes like peroxidases, can easily diffuse out [6]. In order to overcome this problem several approaches were tried including coating with polylysine or chitosan [7]. Chemical modification of polymers or enzymes can introduce new functional groups that also promote enzyme immobilization and adsorption to the gel [8].

Alginate was used previously for immobilization of soybean peroxidase [9], turnip peroxidase [10] and horseradish peroxidase $[6,11]$ but in most cases, due to

Correspondence: R. Prodanović, Faculty of Chemistry, University of Belgrade, Studentski trg 12, Belgrade, Serbia.

E-mail: rprodano@chem.bg.ac.rs

Paper received: 22 November, 2012

Paper accepted: 27 March, 2013 low molecular weight, approximately $45 \mathrm{kDa}$, leakage of the peroxidase from alginate gel was significant.

In the presented research article we developed a novel method for peroxidase immobilization within alginate hydrogel by chemically modifying enzyme molecules and introducing new functional groups into alginate through periodate oxidation.

\section{MATERIALS AND METHODS}

\section{Immobilization of native HRP within native alginate}

Sodium alginate was dissolved in the reagent grade water for preparing a $2 \%(\mathrm{w} / \mathrm{v})$ solution. The gel was stored at $4{ }^{\circ} \mathrm{C}$ till further use. Solution of enzyme in water (concentration $1 \mathrm{mg} / \mathrm{ml}$ ) was added to alginate gel to yield final concentration of $0.01 \mathrm{mg} / \mathrm{ml}$. To perform matrix beading, a needle syringe was filled with the solution and the beads were obtained by dripping the bead-forming solution into a solution of $\mathrm{CaCl}_{2}(5.5 \%)$ and mildly stirring for $1 \mathrm{~h}$ to allow beads hardening. The beads were then washed with the same solution of $\mathrm{CaCl}_{2}(20 \mathrm{ml})$ and stored in HEPES buffer (10 $\mathrm{mM}, \mathrm{pH}$ 7) with $5 \mathrm{mM} \mathrm{CaCl}_{2}$ at $4{ }^{\circ} \mathrm{C}$.

\section{Activation of alginate by oxidation}

Sodium alginate $(1 \mathrm{~g})$ was added to $100 \mathrm{ml}$ of sodium periodate solution $(50 \mathrm{mM})$ at $4{ }^{\circ} \mathrm{C}$ in the dark for activation. The reaction was stopped after $24 \mathrm{~h}$ by adding an equimolar amount of glycerol. $\mathrm{NaCl}(2 \mathrm{~g}$ ) was then added to the mixture, in order to facilitate the subsequent precipitation in the excess of ethanol $(3$ volumes). The precipitate was collected, redissolved in distilled water $(10 \mathrm{ml})$ and dialyzed for $24 \mathrm{~h}$ to remove completely the sodium periodate and other chemicals 
or byproducts. After that, the polymer was precipitated and washed three times in $100 \%(\mathrm{v} / \mathrm{v})$ ethanol, filtered, then dried with pure acetone. The obtained activated alginate product was conserved at room temperature.

\section{Immobilization of native HRP within periodate oxidized alginate}

Activated alginate was dissolved in $0.2 \mathrm{M} \mathrm{NaHCO}_{3}$, $\mathrm{pH} 8.0$, to yield final concentration of $2 \%(\mathrm{w} / \mathrm{v})$, while stirring. After dissolving, HRP was added to the alginate solution, final concentration $0.01 \mathrm{mg} / \mathrm{ml}$. Enzyme immobilization was continued for $24 \mathrm{~h}$ at $4{ }^{\circ} \mathrm{C}$. Finally, $50 \mathrm{mM}$ Tris buffer $\mathrm{pH} 7.0$ (up to $1 / 4$ of the final volume), was introduced drop by drop into the solution to quench the remaining noncoupled (if any) carbonyl groups. The bead forming solution was obtained by addition of $2 \%(\mathrm{w} / \mathrm{v})$ of native alginate at $1: 1$ ratio to the alginate-HRP conjugate solution. Additional non-modified alginate is essential to improve the mechanical properties of beads, because the structure of activated alginate was altered during periodate oxidation. The same procedure was employed for alginate matrix beading as described previously for native alginate.

\section{Modification of HRP with etylenediamine}

Peroxidase (1 mg) was dissolved in $2 \mathrm{ml}$ of $50 \mathrm{mM}$ $\mathrm{NaHCO}_{3}$ buffer, $\mathrm{pH} 8.0$, followed by adding $200 \mu \mathrm{L}$ of 50 $\mathrm{mM}$ sodium periodate. The solution was left at $4{ }^{\circ} \mathrm{C}$ in the dark for $6 \mathrm{~h}$, stirring occasionally. After $6 \mathrm{~h}, 10 \mu \mathrm{L}$ of glycerol was added to the final solution and allowed to settle for $30 \mathrm{~min}$. Finally, the solution was placed for dialysis against distilled water.

Periodate oxidized HRP was mixed with ethylenediamine (50 $\mathrm{mM}$ final concentration, $\mathrm{pH}$ 8.0) for $2 \mathrm{~h}$, followed by addition of $\mathrm{NaBH}_{4}$ in $0.1 \mathrm{M} \mathrm{NaOH}$, final concentration being $1 \mathrm{mg} / \mathrm{ml}$, for $60 \mathrm{~min}$ at $4{ }^{\circ} \mathrm{C}$. Unreacted ethylenediamine was removed by dialysis against $0.1 \mathrm{M}$ sodium phosphate buffer, $\mathrm{pH}$ 7.0, and after that, against distilled water. Obtained HRP was kept in a freezer.

Immobilization of aminated HRP in periodate oxidized alginate was performed as previously described for immobilization of native HRP within periodate oxidized alginate.

\section{Modification of periodate oxidized alginate with ethylenediamine}

Periodate oxidized alginate $(0.4 \mathrm{~g})$ was dissolved in $10 \mathrm{ml}$ of $\mathrm{NaHCO}_{3}$ buffer $(\mathrm{pH} 8.0)$, then $10 \mathrm{ml}$ of $0.1 \mathrm{M}$ ethylenediamine was added and the mixture was left in the dark for $30 \mathrm{~min}$. After that $0.05 \mathrm{~g} \mathrm{NaBH}_{3}$ (CN) was added and left overnight. This solution was placed for dialysis against distilled water.

Immobilization of periodate oxidized HRP in aminated alginate was performed as previously described for immobilization of native HRP within periodate oxidized alginate.

\section{Enzyme activity}

Pyrogallol solution (13 mM) in $10 \mathrm{mM}$ HEPES buffer (pH 7.0) was prepared. Enzyme immobilized beads (50$-80 \mathrm{mg}$ ) were added to $3 \mathrm{ml}$ of thus prepared solution along with $30 \mu \mathrm{l}$ of $0.97 \mathrm{M} \mathrm{H}_{2} \mathrm{O}_{2}$. The mixture was kept for constant stirring on magnetic stirrer and aliquots were taken at $0,5,10$ and $15 \mathrm{~min}$ post-incubation. Absorbance was measured at $420 \mathrm{~nm}$.

Unbound activity was measured in a solution of $\mathrm{CaCl}_{2}$ after gel beading. "Leakage" was measured after $24,48 \mathrm{~h}$ and 5 days, and retained specific activity was measured after 5 days.

\section{RESULTS AND DISCUSSION}

\section{Immobilization of HRP}

In order to efficiently immobilize HRP within alginate beads, different methods of enzyme and alginate modification were tried. Three types of alginate were used: native one, alginate oxidized by periodate and alginate modified with ethylene diamine after periodate oxidation. Three types of HRP were also used, native enzyme, enzyme oxidized by periodate and enzyme modified with ethylene diamine after periodate oxidation. Enzyme concentration used for immobilization was fixed at $0.01 \mathrm{mg} / \mathrm{mL}$, alginate concentration was $2 \%(\mathrm{w} / \mathrm{v})$ and in order to have better mechanical properties, modified alginate was mixed in 1:1 ratio with $2 \%(w / v)$ native form, just before immobilization. lonotropic gelation with $\mathrm{CaCl}_{2}$ gave beads with average diameter of $1.5 \mathrm{~mm}$ (Figure 1).

Four different combinations of native and modified enzyme and alginate were tried. First, native HRP was immobilized within native alginate and in the second experiment within periodate oxidized alginate. Third, periodate oxidized HRP, according to the protocol we previously developed [12] in order to introduce aldehyde groups, was immobilizied within alginate modified with ethylenediamine after periodate oxidation. Forth experimental setup was HRP modified with ethylenediamine after periodate oxidation immobilized within periodate oxidized alginate.

Based on analysis of enzyme activity after immobilization, it can be concluded that modified alginate and modified enzyme exhibited higher amount of activity compared to the classical method for HRP immobilization within alginate beads (Table 1 ).

Highest activity of $0.43 \mathrm{U} / \mathrm{g}$ was obtained by encapsulation of aminated HRP within oxidized alginate. The same conjugate showed also highest retention of activity after 5 days of washing, which is indicative that enzyme was not only entrapped within alginate matrix, but also covalently bound via aldehyde groups present in oxidized alginate. Aminated HRP immobilized within oxidized alginate was further characterized with res- 


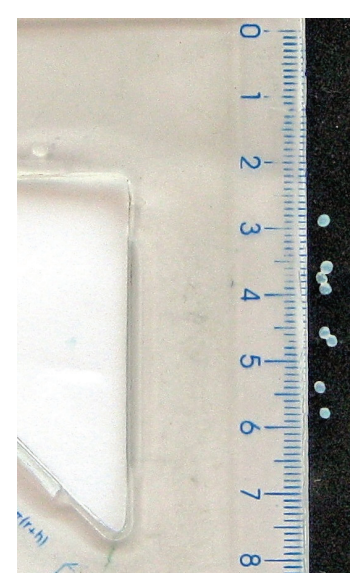

(a)

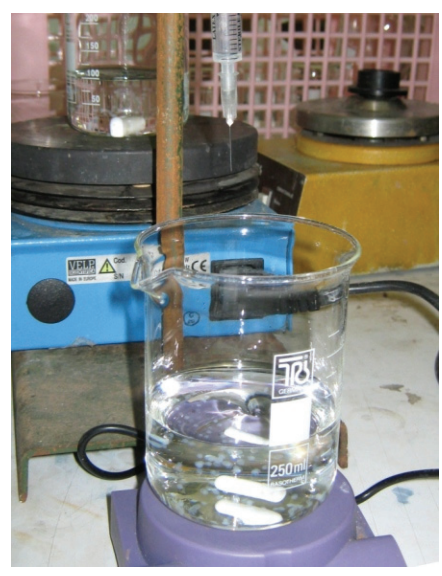

(b)

Figure 1. Beads with immobilized enzyme after gelation in $\mathrm{CaCl}_{2}$ solution (a) and setup used for bead formation (b).

pect to $\mathrm{pH}$ optimum, stability in organic solvent and kinetic properties.

\section{pH Influence on activity}

$\mathrm{pH}$ Optimum was determined using acetate, HEPES and glycine buffer. Compared to native HRP, aminated form immobilized within oxidized alginate showed $\mathrm{pH}$ optimum shift towards low values $(\mathrm{pH}<7)$, as in Figure 2.

While in previous studies of peroxidase immobilization within nonmodified alginate, $\mathrm{pH}$ optimum was not changed [11], in our case change in $\mathrm{pH}$ optimum was probably result of introduced charged groups

Table 1. Specific activity, bound activity, percentage of binding, immobilization yield and residual activity within alginate beads for different immobilization methods. Percentage of binding is defined as a ratio of bound activity and activity that was added per gram of alginate gel during immobilization. Immobilization yield is defined as a ratio of specific and bound activity. Residual activity is defined as a ratio of specific activity immediately after immobilization and specific activity after 5 days of rinsing in buffer

\begin{tabular}{lcccccc}
\hline Immobilization method & $\begin{array}{c}\text { Specific } \\
\text { activity, U/g }\end{array}$ & $\begin{array}{c}\text { Bound } \\
\text { activity, U/g }\end{array}$ & $\begin{array}{c}\text { Percentage of } \\
\text { binding, \% }\end{array}$ & $\begin{array}{c}\text { Immobilization } \\
\text { yield, \% }\end{array}$ & $\begin{array}{c}\text { Residual } \\
\text { activity, U/g }\end{array}$ & $\begin{array}{c}\text { Residual } \\
\text { activity, \% }\end{array}$ \\
\hline Alginate + HRP & 0.15 & 0.80 & 9.69 & 18.4 & 0.063 & 42.6 \\
Oxidized alginate + HRP & 0.13 & 1.11 & 9.69 & 11.7 & 0.081 & 62.3 \\
Aminated alginate + oxidized HRP & 0.15 & 1.73 & 14.1 & 8.92 & 0.074 & 48.0 \\
Oxidized alginate + aminated HRP & 0.43 & 5.76 & 81.4 & 7.43 & 0.409 & 95.6 \\
\hline
\end{tabular}

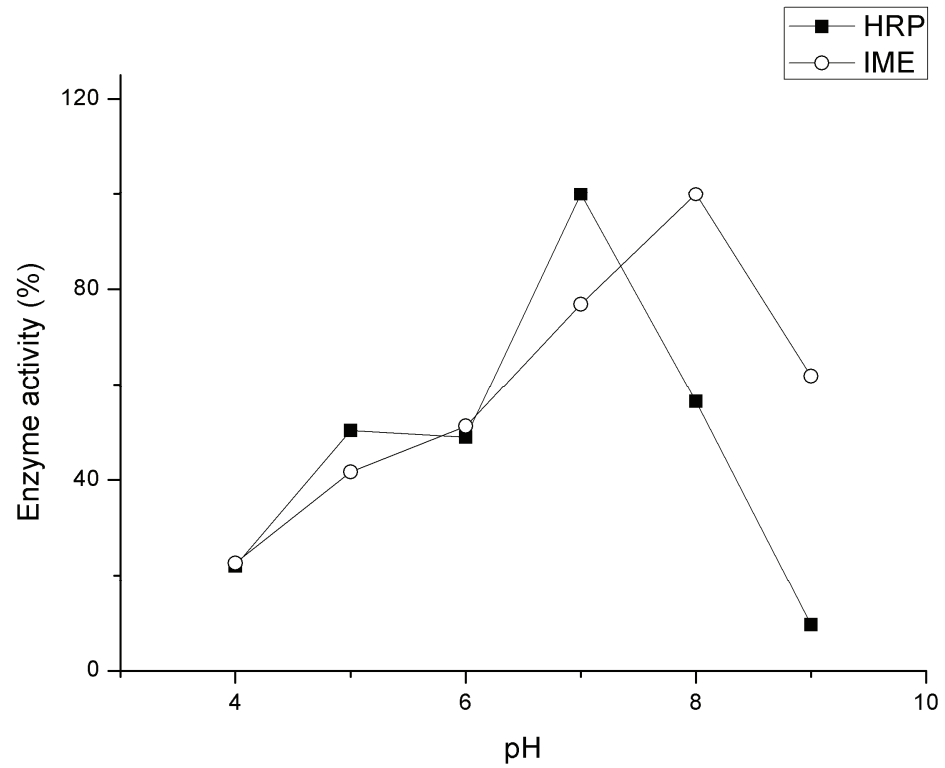

Figure 2. Influence of $\mathrm{pH}$ on activity of free (filled square) and immobilized HRP (open circle). 
within alginate due to chemical modification. Wider $\mathrm{pH}$ optimum and higher activity at more basic $\mathrm{pH}$ values of immobilized HRP makes it more suitable for industrial application since it is less sensitive to changes in $\mathrm{pH}$.

\section{Stability in the presence of dioxane}

Since HRP is also used for polymer synthesis in organic solvents, stability in these media is important for its application. Stability of our immobilized HRP was measured in $80 \%(\mathrm{v} / \mathrm{v})$ dioxane at room temperature $\left(25^{\circ} \mathrm{C}\right)$. After incubation in dioxane water mixture, immobilized enzyme was washed with buffer and residual activity was measured in water solution (Figure 3 ).

Stability of immobilized enzyme in the presence of dioxane increased substantially. While free enzyme was losing $90 \%$ of its original activity after 1 day of incu- bation, immobilized enzyme retained more than $75 \%$ of the original activity after 2 days of incubation in $80 \%$ (v/v) dioxane.

\section{Determination of $K_{\mathrm{m}}$ and $V_{\max }$}

$K_{\mathrm{m}}$ value for pyrogallol of free enzyme is $2.24 \mathrm{mM}$, while our immobilized enzyme showed $K_{\mathrm{m}}$ value of 4.86 $\mathrm{mM}$ (Figure 4).

These results were in good agreement with previous reports for enzymes immobilized within alginate gels and they appear to be a result of diffusional limitations that occur within alginate beads.

\section{Repeated cycle testing in batch reactor}

At the end aminated HRP immobilized within beads made from oxidized alginate was tested in a batch reactor for repeated use during pyrogallol oxidation.

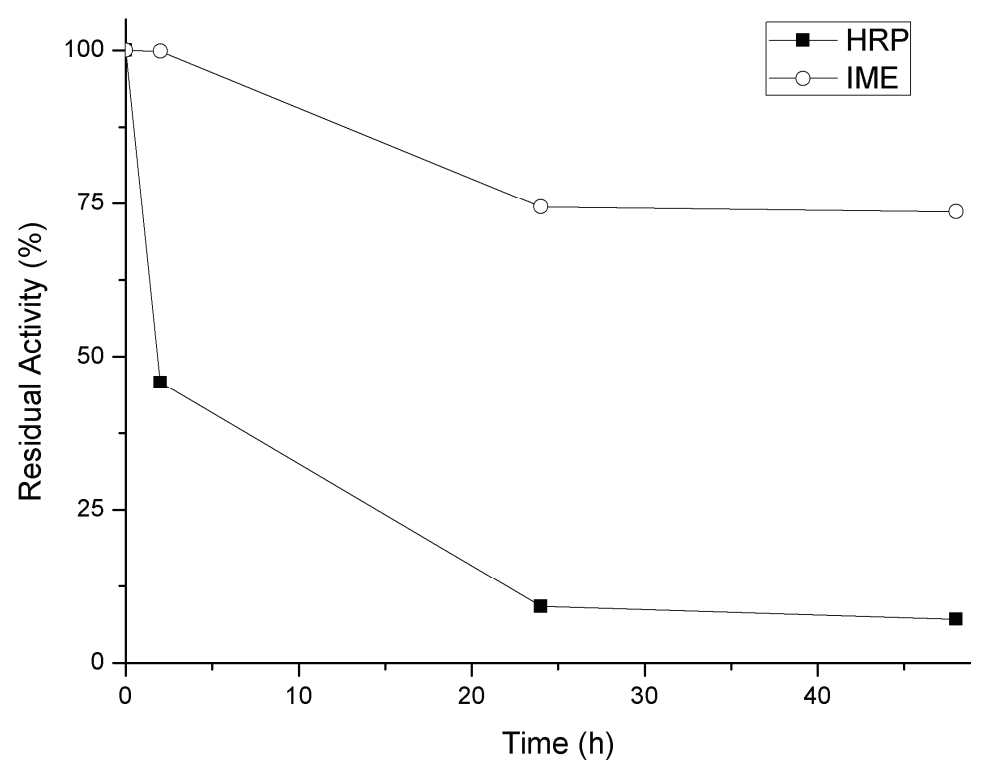

Figure 3. Influence of incubation time in $80 \%(\mathrm{v} / \mathrm{v})$ dioxane on residual activity of free and immobilized HRP.

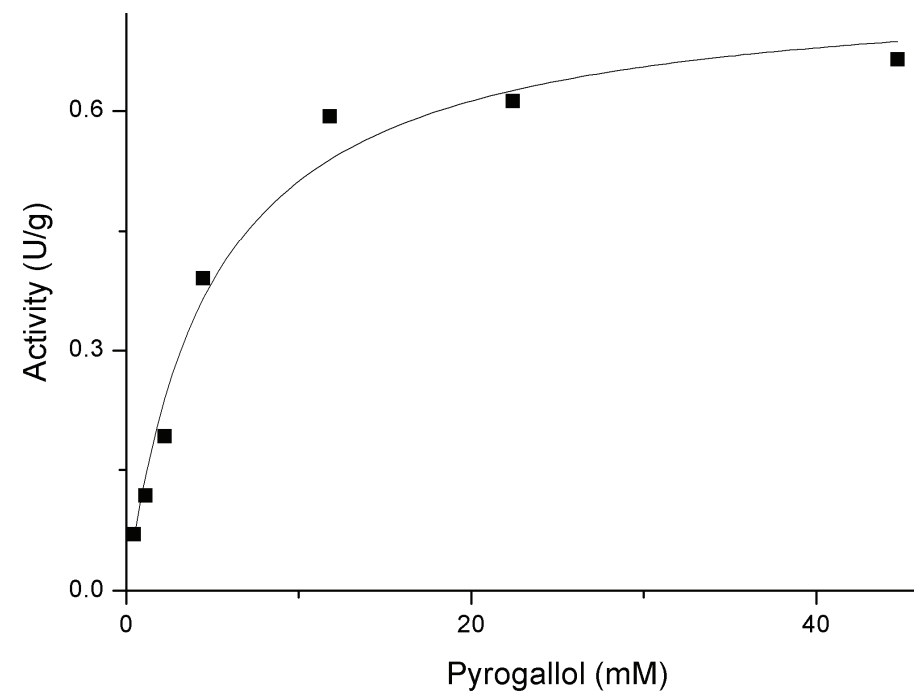

Figure 4. Michaelis-Menten curve for immobilized HRP. 
Each cycle lasted for $6 \mathrm{~h}$ and afterwards, amount of oxidized pyrogallol was determined spectrophotometrically while beads were washed and reused (Figure 5).

After first cycle, immobilized enzyme lost some of the activity, but later activity remained unchanged through 5 cycles of repeated use. This was a better result than previously reported for HRP immobilized within native alginate [6] where activity after 5 cycles dropped below $40 \%$ of the original value. This makes our immobilized HRP a suitable candidate for application in industry where operational stability is of the utmost importance.

\section{Acknowledgment}

This work was supported by Grant No. ON173017 and Grant No. ON172049 sponsored by the Ministry of Education, Science and Technological Development, Republic of Serbia.

\section{REFERENCES}

[1] A.M. Klibanov, Z. Berman, B.N. Alberti, Preparative hydroxylation of aromatic compounds catalyzed by peroxidase. J. Am. Chem. Soc. 103 (1981) 6263-6264.

[2] Q. Husain, R. Ulber, Immobilized Peroxidase as a Valuable Tool in the Remediation of Aromatic Pollutants and

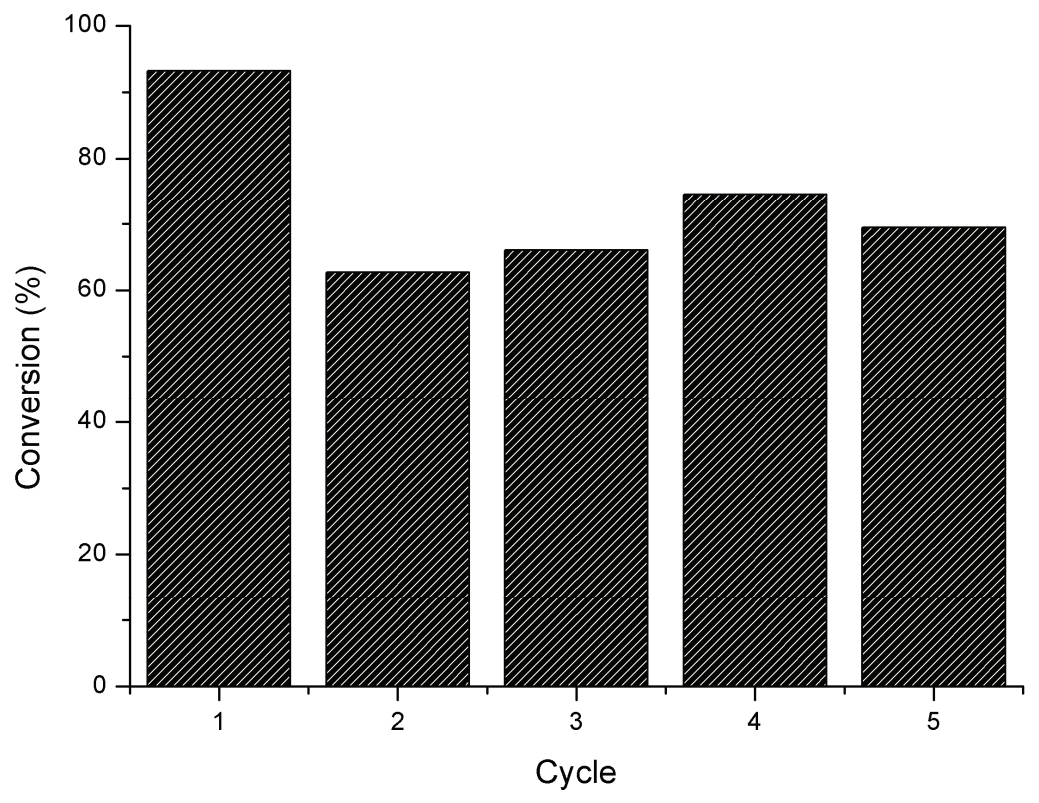

Figure 5. Activity of immobilized HRP during repeated batch run.

\section{CONCLUSION}

We have developed the protocol for efficient immobilization of HRP within alginate beads. In order to improve immobilization efficiency, HRP was modified with ethylenediamine and at the same time alginate was oxidized with sodium periodate to introduce reactive aldehyde groups into polysaccharide backbone. Due to those modifications enzyme was covalently bound to the alginate beads and could not be released after subsequent washing or repeated use in batch reactor. Immobilized enzyme also showed high stability in the presence of organic solvents and increased tolerance to $\mathrm{pH}$ changes. In a batch reactor it could be used in 5 consecutive rounds for pyrogallol oxidation without significant loss of enzymatic activity. Therefore, thus prepared immobilized HRP is a suitable candidate for industrial application in phenol removal or polymer synthesis in monophasic organic solvent and aqueous solutions.
Xenobiotic Compounds, Review. Crit. Rev. Env. Sci. Tec. 41 (2011) 770-804.

[3] G.V. Presnova, M.Y. Rybcova, A.M. Egorov, Electrochemical biosensors based on horseradish peroxidase, Russ. J. Gen. Chem. 78 (2008) 2482-2488.

[4] D. Brady, J. Jordaan, Advances in enzyme immobilisation, Biotechnol. Lett. 31 (2009) 1639-1650.

[5] J.K. Park, H.N. Chang, Microencapsulation of microbial cells, Biotechnol. Adv. 18 (2000) 303-319.

[6] S.V. Mohan, K.K. Prasad, N.C. Rao, P.N. Sarma, Acid azo dye degradation by free and immobilized horseradish peroxidase (HRP) catalyzed process, Chemosphere $\mathbf{5 8}$ (2005) 1097-1105.

[7] Y.J. Hong, M.S. Lee, J.C. Kim, pH-dependent release of alginate beads coated with polylysine, J. Ind. Eng. Chem. 17 (2011) 410-414.

[8] R.C. Rodrigues, A. Berenguer-Murcia, R. Fernandez-Lafuente, Coupling Chemical Modification and Immobilization to Improve the Catalytic Performance of Enzymes, Adv. Synth. Catal. 353 (2011) 2216-2238. 
[9] U.J. Trivedi, A.S. Bassi, J. Zhu, Investigation of phenol removal using sol-gel/alginate immobilized soybean seed hull peroxidase, Can. J. Chem. Eng. 84 (2006) 239$-247$.

[10] F. Quintanilla-Guerrero, M.A. Duarte-Vazquez, B.E. Garcia-Almendarez, R. Tinoco, R. Vazquez-Duhalt, C. Regalado, Polyethylene glycol improves phenol removal by immobilized turnip peroxidase, Bioresource Technol. 99 (2008) 8605-8611.
[11] I. Alemzadeh, S. Nejati, Removal of Phenols with Encapsulated Horseradish Peroxidase in Calcium Alginate, Iran. J. Chem. Chem. Eng. 28 (2009) 43-49.

[12] O. Prodanovic, M. Prokopijevic, D. Spasojevic, K. Radotic, Z. Knezevic-Jugovic, R. Prodanovic, Improved Covalent Immobilization of Horseradish Peroxidase on Macroporous Glycidyl Methacrylate-Based Copolymers, App. Biochem. Biotechnol. 168 (2012) 1288-1301.

\section{IMOBILIZACIJA HEMIJSKI MODIFIKOVANE PEROKSIDAZE IZ RENA UNUTAR AKTIVIRANIH ALGINATNIH KUGLICA}

Dragica Spasojević ${ }^{1}$, Miloš Prokopijević ${ }^{1}$, Olivera Prodanović ${ }^{1}$, Marilen Gabriel Pirtea ${ }^{2}$, Ksenija Radotić ${ }^{1}$, Radivoje Prodanović ${ }^{3}$

${ }^{1}$ Institut za multidisciplinarna istraživanja, Univerzitet u Beogradu, Beograd, Srbija

${ }^{2}$ Multidisciplinary research platform "Nicholas Georgescu-Roegen", West University of Timisoara, Timisoara, Romania

${ }^{3}$ Hemijski fakultet, Univerzitet u Beogradu, Beograd, Srbija

(Naučni rad)

Imobilizacija peroksidaze iz rena unutar alginatnih kuglica je poboljšana hemijskom modifikacijom enzima i polisaharidnih lanaca. Peroksidaza i alginat su oksidovani perjodatom i naknadno modifikovani etilendiaminom. Najveća specifična aktivnost od 0,43 $\mathrm{U} / \mathrm{ml}$ gela i $81 \%$ vezane aktivnosti je dobijeno korišćenjem aminovane peroksidaze i alginata oksidovanog perjodatom. Imobilizovani enzim je zadržao 75\% originalne aktivnosti nakon 2 dana inkubacije u $80 \%$ (v/v) dioksanu i imao je povećanu aktivnost pri baznim pH vrednostima u poređenju sa nativnim enzimom. Tokom višestruke upotrebe u šaržnom reaktoru za oksidaciju pirogalola imobilizovana peroksidaza je zadržala $75 \%$ početne aktivnosti.
Ključne reči: Perjodat • Etilendiamin • Peroksidaza • Imobilizovan 